\title{
The Tiebout Hypothesis Of Voting With One's Feet: A Look At The Most Recent Evidence
}

\author{
Richard J. Cebula*
}

\section{INTRODUCTION}

Geographic movement to express one's preferences for public goods is referred to as "voting with one's feet." The process of voting with one's feet is traceable to the hypothesis by Tiebout $(1956$, p. 418) that:

... the consumer-voter may be viewed as picking that community which best satisfies his preference pattern for public goods ... the consumer voter moves to that community whose local government best satisfies his set of preferences.

The Tiebout hypothesis above has been investigated by a large number of researchers; however, all of the studies to date have dealt with the behavior of consumer-voters prior to the 1970's. Accordingly, the purpose of this Note is to examine the Tiebout hypothesis for the 1970's (specifically, the period 1970-1977) using the most recent appropriate data available. $^{1}$

\section{THE ANALYSIS}

To investigate the behavior of consumer-voters, we estimate the following regressions:

(1) $\mathrm{MWi}=\mathrm{a}_{0}+\mathrm{a}_{1}$ YMEDi $+\mathrm{a}_{2}$ AFDCi $+\mathrm{a}_{3}$ PCEDi $+\mu_{1}$

(2) $\quad$ MWi $=b_{0}+b_{1}$ YMEDi $+b_{2}$ AFDCi $+b_{3}$ PCEDi $+b_{4}$ PROPTXi $+\mu_{2}$

where $a_{0}, b_{0}=$ constants

$$
\begin{aligned}
\mathrm{MWi} & =\text { net in-migration rate of whites to state } \mathrm{i}, 1970-1977 \\
\mathrm{YMEDi} & =\text { median income in state } \mathrm{i}, 1969
\end{aligned}
$$



AFDCi = average level, per recipient family, of aid to families with dependent children (AFDC) in state $i, 1972$

PCEDi = per capita public school expenditures in state i, 1971

PROPTXi = per capita property tax in state $\mathrm{i}, 1971$

$$
\mu_{1}, \mu_{2}=\text { error terms }
$$

The above two models consider the consumer-voter behavior of whites during the period 1970-1977. The equations include the most basic, standard variable in all mobility studies, income. The equations also include those three public-policy variables which were found to influence white migration patterns during the 1950's and 1960's, namely, welfare levels, education spending, and property taxation. Equation (1) includes only two of the three public policy variables, welfare benefits and spending on public education. These a the two policy variables examined most commonly in the previous literature on migration and the Tiebout hypothesis. Moreover, these two variables may both be viewed as measuring potential benefits of public policy. Equation (2) differs from equation (1) by its inclusion of the tax variable. Presumably, this addition to the model may permit the migrant to appraise expressly both the benefits and the costs associated with public policy.

The data dealt with here are the most recent appropriate data currently available. The data set includes all 50 states plus the District of Columbia. The data sources were The City and County Data Book, 1977, The Statistical Abstract of the United States, 1971, The Statistical Abstract of the United States, 1977, and The Statistical Abstract of the United States, 1979. The reason for presenting an analysis solely of white consumer-voters is indicated in Section III below. The migration data used in this study are derived from the Census Bureau post-censal estimates for net in-migration of whites. ${ }^{2}$ Unfortunately, there may be problems with the reliability of the data, particularly for the smaller states. Hence, the results presented in this Note must be interpreted as merely tentative.

Estimating (1) and (2) by ordinary least squares yields (3) and (4), respectively:

$$
\mathrm{MWi}=9.03369+\underset{(+1.35)}{0.00849 \mathrm{YMDi}-} \begin{aligned}
& 0.04341 \mathrm{AFDCi}+ \\
& (-3.00)
\end{aligned}
$$

0.04157PCEDi, $\mathrm{DF}=47$, $(+2.45)$

$$
\mathrm{R}^{2}=.52, \mathrm{~F}=5.34
$$




$$
\begin{aligned}
& \mathrm{MWi}=8.91074+\begin{array}{l}
0.00904 \mathrm{YMEDi} \\
(+1.43)
\end{array} \\
& \begin{array}{l}
0.04299 \mathrm{PCEDi} \\
\begin{array}{l}
0.01099 \mathrm{PROPTXi}, \mathrm{DF} \\
(+2.51) \\
(-1.81)
\end{array}
\end{array} \\
& \mathrm{R}^{2}=.62, \mathrm{~F}=4.94
\end{aligned}
$$

where terms in parentheses are t-values.

In terms of the welfare variable, AFDC, the coefficient is significant at the .01 level in both equations with a negative sign. This lends support to the argument by Cebula $(1974$, p. 86$)$ that

... by virtue of the fact that welfare benefits represent a redistribution of income from the economically better-off to the economically worse-off, whites may tend to view areas with higher welfare benefits as areas which on average redistribute income from themselves to others. Thus ... white migrants may be on average expected to gravitate to areas with lower levels of welfare benefits.

In terms of the education spending variable, PCEDi, the coefficient is significant in both equations at the .01 level with a positive sign. Presumably, higher public education outlays per capita act as an attraction to white consumer-voters since the higher such expenditure levels, the greater the commitment to public education. Thus, a higher per capita spending level may, ceteris paribus, raise "fiscal surplus." This result for the period 19701977 is compatible with several studies of earlier periods, including Pack (1973), Cebula (1977), and Renas (1980).

Finally, the property tax variable in equation (4) is negative and significant at the .05 level. This implies that white consumer-voters tend to prefer areas with lower property tax levels. Presumably, areas with higher property tax levels offer a smaller fiscal surplus, ceteris paribus. Moreover, white consumer-voters may view the property tax as a part of the overall cost of living in an area and thus prefer lower property tax areas. In any event, this result for 1970-1977 is compatible with studies of earlier periods, including Pack (1973) and Cebula (1974).

\section{CONCLUSION}

The Tiebout hypothesis of voting with one's feet has been examined for the years prior to the 1970's by numerous researchers. The present Note is the first paper to consider the hypothesis for the 1970's per se. The findings presented above indicate that white consumer-voters over the period 1970-1977 did in fact vote with their feet with respect to welfare, public education, and property taxation; furthermore, the results pre. 
sented here are entirely compatible with those of earlier periods (the 1950's and 1960's).

In closing, it should be noted that numerous regressions such as those above were estimated for nonwhite consumer-voters over the 1970-1977 period. In every case, the public-policy variables were statistically insignificant; for this reason, there was no need to present the results here. Thus, the phenomenon of "voting with one's feet" apparently applied during this period only for white consumer-voters.

\section{FOOTNOTES}

${ }^{1}$ Most of the more recent empirical investigations of the Tiebout hypothesis have involved the relationship between migration (as the dependent variable) and various public policy variables. It should be noted that many examinations of the Tiebout hypothesis concentrate on the capitalization of taxes and spending into property values rather than on migration per se. Oates (1969, p. 968 ) finds that individuals consider public services and taxes and concludes, based on property value date, that "... people do appear willing to pay more to live in a community which provides a high quality of public services (or in a community which provides the same program of public services with lower tax rates)." Hamilton (1976) agrues that it is the interjurisdictional differences in tax rates and public services which are capitalized into property values (positive value for fiscal surplus), not the absolute intrajurisdictional differences. Furthermore, he argues that if the interjurisdictional differences are capitalized, there is no horizontal inequity. with complete capitalization, two identical public service bundles may have different tax liabilities in different areas, but the fiscal surplus will be exactly offset by differences in property values, implying that the two areas are equally attractive and that there is no incentive to migrate to the area with the fiscal surplus. The findings of Oates (1969) and of Edel and Sclar (1974) are that capitalization is not complete. Thus, we do expect to observe migration in response to the uncapitalized fiscal surpluses. Capitalization tests of the Tiebout hypothesis attempt to clarify the nature of the incentive to migrate and highlight the disequilibrium nature of the migration.

${ }^{2}$ The Statistical Abstract of the United States, 1979, Section

\section{REFERENCES}

Cebula, R. J., "Local Government Policies and Migration: An Analysis for SMSA's in the United States, 1965-1970," Public Choice, Fall, 1974, pp. 85-93.

Cebula, R. J., "An Analysis of Migration Patterns and Local Public Policy Toward Public Education," Public Choice, Winter, 1977, pp. 113-121.

Edel, M. and E. Sclar, "Taxes, Spending, and Property Values: Supply Adjustment in a Tiebout-Oates Model," Journal of Political Economy, September/ October, 1974, pp. 941-955.

Hamilton, B. W., "Capitalization of Intrajurisdictional Differences in Local Tax Prices," American Economic Review, December, 1976, pp. 743-753.
Oates, W. E., "The Effects of Property Taxes and Local Spending on Property Values: An Empirical Study of Tax Capitalization and the Tiebout Hypothesis," Journal of Political Economy, November/December, 1969, pp. 957-971.

Pack, J., "Determinants of Migration to Central Cities," Journal of Regional Science, August, 1973, pp. 249-260.

Renas, S. M., "An Empirical Note on the TieboutTullock Hypothesis: Comment," Quarterly Journal of Economics, May, 1980, pp. 619-623.

Tiebout, C. M., "A Pure Theory of Local Expenditures," Journal of Political Economy, October, 1956, pp. 416424 . 